\title{
Fostering Micro-Entrepreneurship as Panacea to Poverty Eradication in the Malaysian Economy: A Conceptual Perception
}

\author{
Muhammad Abi Sofian Abdul Halim ${ }^{1}$, Zainuddin Zakaria ${ }^{1}$, Azemi Che Hamid ${ }^{1} \&$ Mohamad Kamil Ariff \\ Khalid $^{1}$ \\ ${ }^{1}$ Faculty of Business Management, Universiti Teknologi MARA (Terengganu), Campus of Chendering, 21080, \\ Kuala Terengganu, Terengganu, Malaysia \\ Correspondence: Muhammad Abi Sofian Abdul Halim, Faculty of Business Management, Universiti Teknologi \\ MARA (Terengganu), Campus of Chendering, 21080, Kuala Terengganu, Terengganu, Malaysia. Tel: \\ 13-920-4322. E-mail: abisofian@tganu.uitm.edu.my
}

Received: April 23, 2014 Accepted: June 4, 2014 Online Published: June 25, 2014

doi:10.5539/ass.v10n13p287

URL: http://dx.doi.org/10.5539/ass.v10n13p287

\begin{abstract}
Entrepreneurs not only create benefits through the expansion and the development of economic and business industry, it also creates challenges for emerging micro-entrepreneurs to effectively compete in an environment characterised by multitude of challenges. The question is whether the development of micro-entrepreneurship industry is a progressive approach that can motivate the small and medium entrepreneurs to eradicate poverty. This paper is a deliberate attempt to revisit the essential concept and practice of micro-entrepreneurship in small and medium industry as well as its role in eradicating poverty in Malaysian. The Malaysian government has launched the New Economic Policy to eradicate hardcore poverty, restructuring employment and developing the rural area of Malaysia. It has been determined that the development of micro-entrepreneurship significantly contributed to small and medium industry and poverty eradication. Furthermore, the success of poverty eradication has significantly created awareness among micro-entrepreneurs in small and medium industry. In this paper, a comprehensive model of micro-entrepreneurship strategy in small and medium industry in eradicating poverty has been constructed with the aim of assisting the Malaysia government in developing their socio-economic policies.
\end{abstract}

Keywords: micro-entrepreneurship, poverty eradication, socio-economy, small and medium industry, government policies

\section{Introduction}

Over the past few decades, Malaysia has embarked on an ambitious and long process of economic, social, and political reforms to improve the Malaysian socio-economic health, increase entrepreneurial awareness and combat poverty at all level of society. Entrepreneurship is recognized by the Malaysian government as an important building block of the national economies, contributing significantly to employment expansion and poverty alleviation. As stated by Zindiye and Mwangolela (2007), the process of poverty eradication has to be supported by of entrepreneurial development programmes. Therefore, entrepreneurship development is a crucial tool to empower micro-entrepreneurs which may lead to drastic poverty reduction.

Recently, the contribution of micro-entrepreneurship programs in assisting the small and medium entrepreneurs to eradicate poverty has been featured prominently in the Malaysia socio-economy policy. The Malaysia business environment is characterised with many challenges for new entrepreneurs and those who are operating in micro and small business scale. Most of the challenges range from lack of energy to stiff competitors, inferior skill and entrepreneurial personality, poor financial management, and high external locus of control. Thus, the practice of entrepreneurship concepts has a prominent role in constructing the micro-entrepreneurs in the context of knowledge expansion, skill development and entrepreneurial traits. Even though the Government of Malaysia has formulated several policies and schemes under the Ministry of Entrepreneurship and Cooperation Development and Ministry of Rural Area Development by enabling policies to extend support to the micro-enterprises, the impact of such schemes and policies has not yielded the desired results. Therefore, it is indeed necessary for the government to take pro active measures in implementing a more effective policies and schemes. In order to enhance the government schemes and policies, this conceptual paper was constructed to 
identify the practical model of micro-entrepreneurship toward the small and medium industry in eradicating poverty in Malaysia. The model proposed in this paper is based on literature review with regards to micro-entrepreneurship and poverty eradication.

\section{Poverty Eradication in Malaysia Socio-Economy}

As argued by previous literature, a lot more classifications has been explained to defined the term of poverty, such as; human under-development, social exclusion, ill-being, lack of capability and functioning, unable to sustain a livelihood, lack of basic needs and relative deprivation (Ofori, 2008). On the other hand, the term poverty also discussed the economic scenario of an industry which include unemployment, lower opportunities in the labour market, and unorganized industry. Thus, it is pivotal to promote self-employment and micro-enterprise development in addressing the issue of poverty, unemployment and inclusive ggrowth. In Malaysia, the issue of poverty has been an age-long problem with a small proportion of its citizen. Similar to other developing countries, it has taken a long time to implement the policies of poverty eradication through the concept of micro-entrepreneurship. Through the New Economic Policies (NEP) in 1970, Malaysian government has emphasized the development of human capital as well as a driver to the economy with the main aim to lead to socio-economic transformation. Furthermore, micro-enterprises have been recognised as an important constituent of the Malaysia economies and contributing significantly to poverty eradication.

Governments all over the world are becoming interested in the growing development of entrepreneurial economy, since entrepreneurial activity is widely seen as an engine of economic growth. The Malaysian government plays a prominent role in poverty eradication efforts by promoting income-generating projects, providing amenities to improve the quality of life and implementing programmes to inculcate positive values among the poor. As well as to eradicated the poverty, several government corporations has been developed to implements these policies such as the Federal Land Development Authority (FELDA), Federal Land Consolidation and Rehabilitation Authority (FELCRA) and the Rubber Industry Smallholders Development Authority (RISDA). These corporations contribute to the policy by developing special schemes and projects to eradicate hardcore poverty. At present, the practice of social-entrepreneurship in NEP can be considered to develop better human-life, industrial expansion, job opportunities, and also entrepreneurial education. In addition, NEP also functions to address the issue of income imbalance particularly among and within ethnic groups, income groups, economic sectors, regions and states.

\section{Literature Review}

According to Ab Aziz Yusof (2009), Small and Medium Industries Development Corporation (SMIDEC) has classified small business as an enterprise with paid-up capital of less than RM500000 and medium-sized with paid-up of RM500001 to RM2.5 million. Furthermore, Ab Aziz Yusof (2009) also highlighted that micro enterprises are bodies which have paid-up capital of less than RM50000. Based on this categorization, the researcher has come up with a solution that can divide the paid-up capital into three categories, such; the paid-up below RM50,000 for micro business size; between RM50,001 to RM500,000 for business in small size; and RM500,001 to RM2,500,000 for business in medium size. SMIDEC has also determined the classification of micro, small and medium size of business by the number of employees, such as; micro business size which has less than 5 employees, small business size which has between 6 to 24 employees, and medium size of business which has above 25 employees Table 1 depicted the number of employees according to the classification of business categorizes which is determined by SMIDEC (Mohd Khairudin Hashim, 2007; Ab Aziz Yusof, 2009). Based on the literature, the terminology of micro-entrepreneurship can be defined as a business which is related to the micro-enterprise activity in a small operating, often registered, having five or fewer employees and requiring seed capital of not more than RM50000 as mentioned in a table 1.

Table 1. Differentiate of paid-up capital and number of employees

\begin{tabular}{ccc}
\hline Category & Paid-up Capital & Number of Employees \\
\hline Micro Business Size & Below RM50,000 & Below 5 employees \\
Small Business Size & RM50,001 - RM500,000 & $6-24$ employees \\
Medium Business Size & RM500,001 - RM2,500,000 & Above 25 employees \\
\hline
\end{tabular}

Many scholars argue that the development of developing countries are significantly contributed by the political and economical stability which affected the entrepreneurial awareness and poverty eradication. In fact, the 
previous study has show that most of developing countries has begun the policies regarding micro-entrepreneurship in poverty eradication, such Nigeria (Agbalajobi, 2011); Ghana (Ofori, 2008), Africa (Zindiye \& Mwangolela, 2007), and Tanzania (Mfaume and Leonard, 2004).

According to Zindiye and Mwangolela (2007), the strategic poverty eradication in Africa was determined by five point approaches to develop the small, micro and medium enterprises. These approaches are financial resources capacity, human capital development (knowledge management), and technologies, the direction to women and youth, and social capital development. An initiative of African in poverty eradication has impacted the socio-economic programs, in term of employment creation, income generation, and improvement of local economies and general social transformation of livelihoods in different geo-political contexts in South Africa. Furthermore, Ofori (2008) has noted that rich entrepreneurs play a prominent role to reduce poverty as well as to inject substantial amounts of money into the economy, to share the wealth with the poor, and providing job opportunities. These efforts brought high impact to the social and economic development of Ghana in the context of; rarely conducive to attracting investment, the potential of employment opportunities, and decreasing of poverty rate, as mentioned in table 2 .

Table 2. Past literature of poverty eradication and its impact

\begin{tabular}{|c|c|c|}
\hline Authors & Strategy on Poverty Eradication & Impact \\
\hline $\begin{array}{c}\text { Zindiye \& Mwangolela } \\
\text { (2007) }\end{array}$ & $\begin{array}{ll}\text { - } & \text { Financial resources capacity. } \\
\text { - } & \text { Human capital development } \\
\text { (knowledge management) } \\
\text { - } & \text { Technologies } \\
\text { - } & \text { The direction to women and youth } \\
\text { - } & \text { Social capital development }\end{array}$ & $\begin{array}{l}\text { - } \\
\text { - } \text { Incomployment creation } \\
\text { - } \\
\text { Improvement of local } \\
\text { economies } \\
\text { - General social transformation } \\
\text { of livelihoods }\end{array}$ \\
\hline Ofori (2008) & $\begin{array}{l}\text { - Rich entrepreneurs inject substantial } \\
\text { amounts of money into the economy. } \\
\text { Entrepreneurs need to share their } \\
\text { wealth with the poor. } \\
\text { - Providing jobs for the people }\end{array}$ & $\begin{array}{l}\text { Economic policies are rarely } \\
\text { conducive to attracting } \\
\text { investment. } \\
\text { - Potential employment } \\
\text { opportunities. } \\
\text { The poverty rate becomes } \\
\text { decrease. }\end{array}$ \\
\hline Ferdman (2007) & $\begin{array}{l}\text { - Creating their own microenterprises } \\
\text { thus becomes a tool of } \\
\text { self-empowerment. } \\
\text { - Offering a way of achieving economic } \\
\text { independence. } \\
\text { - Constituting the only option for } \\
\text { survival. }\end{array}$ & $\begin{array}{l}\text { Increased income brings with } \\
\text { it access to health. } \\
\text { - Create better social services. } \\
\text { - Increase education service. }\end{array}$ \\
\hline Vincent (2006) & $\begin{array}{l}\text { - Sustainable micro-entrepreneurship } \\
\text { - The servicing of micro-finance in } \\
\text { micro and small business. }\end{array}$ & $\begin{array}{l}\text { - Improving the quality of all } \\
\text { human lives. } \\
\text { Help the poor expand their } \\
\text { economic activities and } \\
\text { increase their incomes. } \\
\text { An enabling environment for } \\
\text { the growth of political } \\
\text { participation and democracy. }\end{array}$ \\
\hline
\end{tabular}

Meanwhile Ferdman (2007) mentioned that promoting small and micro scale enterprises is one of the means of eradicating poverty and is a joint effort between local, national and international organizations. It has to be part 
of a comprehensive plan for raising the standard of living of the population. According to Vincent (2006), the concept of sustainable micro-entrepreneurship is a development process combining the three aspects of microfinance, entrepreneurship and sustainability. Sustainable Micro-entrepreneurship is a small-scale, self-sustaining active development process initiated by the poor to help themselves break free from their poverty.

\section{The Concept of Micro-Entrepreneurship in Poverty Eradication}

Basically, the study of economics deal with how scarce resources are allocated to maximize unlimited wants that we want to fulfill (Hashim Ali, 1997). However, each group of people in economic are satisfied in different perspective, where those consumers are really want to maximize their satisfaction and minimize expenditure. Producers, however want to maximize profits and minimize costs (Schumpeter, 1934). Further, the government plays a prominent role in providing a high standard of living for the people. This concept paper emphasize the producers and relating to the concept of entrepreneurship as well as a driving force behind changes in the economy. According to Kirzner and Sautet (2006), the fundamental of entrepreneurship definition comprises human creativity and the ability to discover profitable ideas that enable market actors to take advantage of new and socially beneficial gains from trade. Meanwhile Ferdman (2007) noted that the eradication of poverty can be determined by the ability of the economist and industrial practitioners to create job opportunities, business opportunities in a better market competition and also investment opportunity. The objective of this paper, therefore is to determine the importance of micro-entrepreneurship in improving the quality of life of people as well to eradicate poverty among citizens of the country.

\section{Conceptual Model}

In general, the study revealed that micro-entrepreneurship training and programs contributes enormously to the growth of industry and poverty eradication, in term of; employment creation, business opportunities, attracting investors, and social transformation of livelihoods. This model has been constructed which included five inter-related variables, namely micro-entrepreneurship, the growth of small and medium industry (SMI), poverty eradication, entrepreneurial awareness, and government policies.

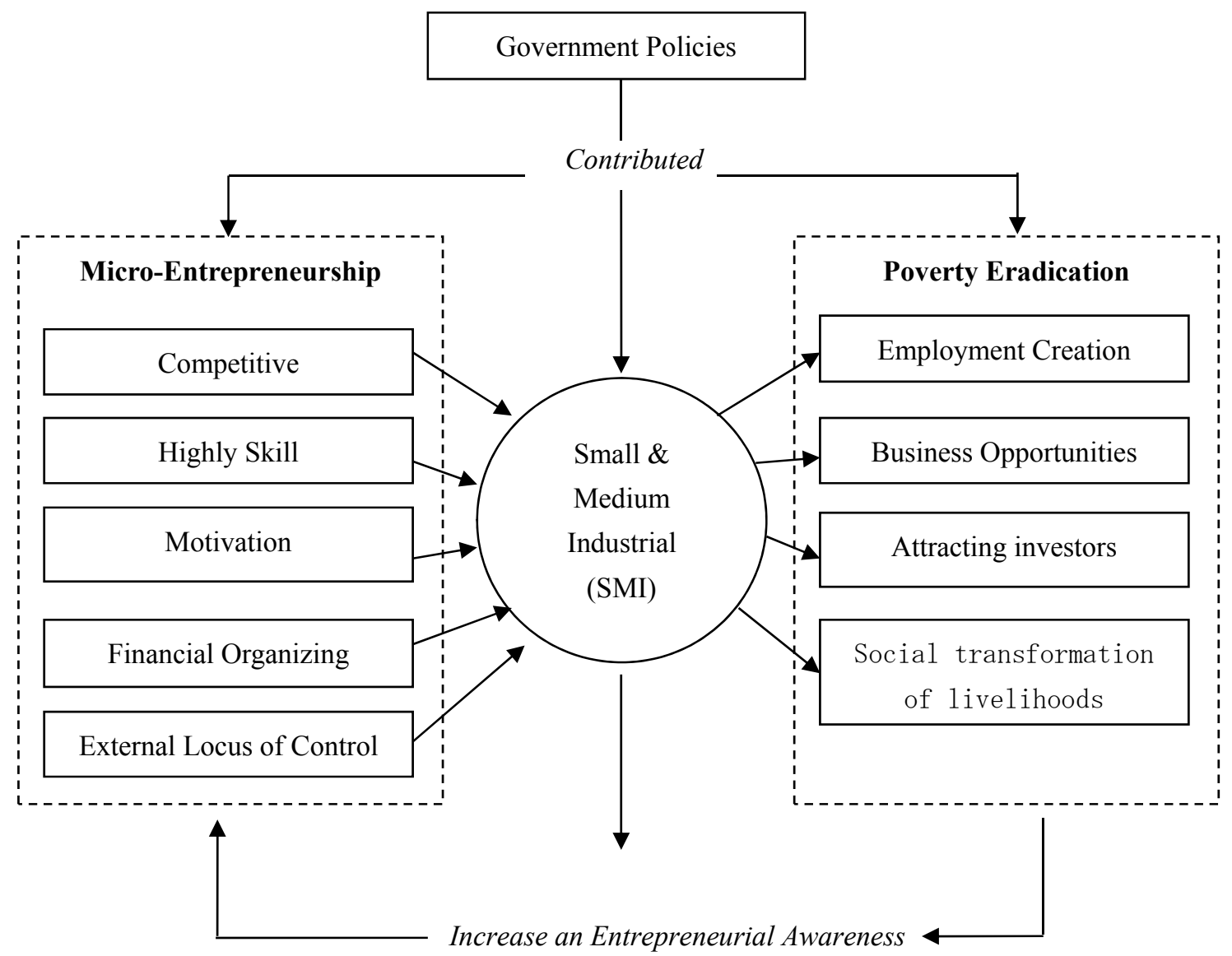

Figure 1. The conceptual model of micro-entrepreneurship and poverty eradication 
First and foremost, this paper have raise an argument at the genesis of this concept that micro-entrepreneurship are the main driver of the Malaysia socio-economy contributed to the growth. The literatures on micro-entrepreneurship theory have argued on the main role of state governments to drive the growth of the SMI. There are several factors of micro-entrepreneurship that have been identified to contribute to SMI which include those entrepreneurs who are very skilful in business and motivation, sense of competitiveness, capability on how to manage the financial aspects in business and being independent. Secondly, factors of opportunities in the development of SMI have become a driver for the micro-entrepreneurs in the eradication of poverty. Thus, the growth of SMI is considered as an emerging component of economic transformation aimed to eradicate poverty and meeting social objectives. Thirdly, the poverty eradication efforts of the entrepreneurship have contributed to the creation of employment and business opportunities, attracting both local and foreign investors, and to increase social livelihood.

Fourth, the construction of this model highlighted the three factors that a government can contribute on. These three factors include government initiative in planning and implementing of policies for micro-entrepreneurs; the relationship between the government and the small and medium industry, and the association between government initiative and poverty eradication. Generally, government's role contributes significantly to the paradigm shift in terms of economic growth as well as the eradication of poverty. The contribution of the Malaysia government is manifested through the growth of small and medium industry and greatly impacts the quality of micro-entrepreneurs by creating social opportunities. Fifth, the positive development of small and medium industry and success in poverty eradication has outlined the association back to increase entrepreneurial awareness as well as to stimulate the growth of micro-entrepreneurship. As well as to describe the concept of this study, a comprehensive model of essential micro-entrepreneurship in eradicating Malaysian poverty was constructing with the aim of contributing to the development of Malaysia socio-economy.

\section{Recommendation for Policy Implication}

As the world economic creates benefits through advanced technologies and expansion of business, it also creates challenges for emerging micro and small business enterprises to effectively compete in an environment characterised by globalisation and unpredictable market. In South Africa for example, there are many social-economic constraints that curtail the development and impact of micro-entrepreneurship programs on poverty eradication in South Africa. This study therefore recommends that:

1. Government should strive harder to provide adequate incentives for micro-entrepreneurs to enable them expand their businesses and also capable to face the global competitors.

2. It is also important to engage the micro-entrepreneurs in entrepreneurial education which is one of the major key elements in promoting entrepreneurship development as well as to stimulate the small and medium industry and eradicate poverty.

3. The government should actively create policies that will positively enhance the participation of micro-entrepreneurs' activities such as reducing rate on loans, making loans accessible, and providing adequate infrastructure

\section{Conclusion}

With regard to the issue of entrepreneurship and poverty eradication, the most plausible conclusion for this paper is the fact that micro-entrepreneurship plays a key role in poverty eradication. This can be inferred from literature that most poverty reduction planning in developing countries are implemented in the micro-entrepreneurship programs. Finally, effort should be made to promote entrepreneurial skills that are accessible to small scale enterprises and enterprises operating in trade, commerce. In addition to the New Economic Policy, other government policies should be restructure to offer effective assistance for micro-enterprise development. The state and local governments can also directly increase the market for micro-enterprise products by improving both rural and urban infrastructure in Malaysia.

\section{References}

Ab. Aziz Yusof. (2009). Pendidikan Keusahawanan dalam Konteks Pembangunan Negara. Kuala Lumpur: Dewan Bahasa \& Pustaka.

Agbalajobi, D. (2011). Fostering Women Entrepreneurship as Panacea to Poverty Reduction in Developing Economy. Department of Political Science and Public Administration College of Management Sciences Redeemer's University Redemption City, Ogun State, Nigeria.

Ferdman, S. (2007). Eradicating Poverty through Enterprise an Israeli Viewpoint. This paper presented to the 
United Nations, New York in 2nd November 2007. The Center for International Cooperation - MASHAV Ministry of Foreign Affairs Israel.

Hashim, A. (1997). Comprehensive Economics Guide. Singapore: Oxford University Press.

Kirzner, I. M., \& Sautet, F. (2006). The Nature and Role of Entrepreneurship in Markets: Implications for Policy. Mercatus Policy Series. Mercatus Center, George Mason University Policy Primer No 4.

Mfaume, R. M., \& Leonard, W. (2004). Small Business Entrepreneurship in Dar es salaam -Tanzania: Exploring Problems and Prospects for Future Development. This paper presented at Forum of African development and Poverty Reduction: The Macro - Micro Linkage. Lord Charles Hotel, Somerset West, South Africa.

Mohd Khairuddin Hashim. (2007). SMEs in Malaysia: A Brief Handbook. Selangor: August Publishing.

Ofori, F. (2008). Entrepreneurship AS THE Key to Poverty Eradication and How the Government of Ghana Treats Entrepreneurs. Graduate Student, University of Ghana, Legon, Accra, Ghana.

Schumpeter, J. A. (1934). The Theory of Economic Development. Cambridge: Harvard University.

Vincent, G. (2006). Sustainable Microentrepreneurship: The Roles of Microfinance, Entrepreneurship and Sustainability in Reducing Poverty in Developing Countries.

Zindiye, S., \& Mwangolela,T. F. (2007). Entrepreneurship a Key to Poverty Reduction and Socio-Economic Development. 1st International Business Conference, Pretoria, Ronald H. Brown Institute for Sub-Saharan Africa

\section{Copyrights}

Copyright for this article is retained by the author(s), with first publication rights granted to the journal.

This is an open-access article distributed under the terms and conditions of the Creative Commons Attribution license (http://creativecommons.org/licenses/by/3.0/). 